\title{
Infection Control in Dentistry- A Review
}

\author{
Shiva Charan Yadav ${ }^{1}$, Babitha G.A ${ }^{2}$, Shobha Prakash ${ }^{3}$ \\ ${ }^{1}$ Post graduate student Department of Periodontics, College of Dental Sciences, Davangere \\ ${ }_{2}^{2}$ Professor, Department of Periodontics, College of Dental Sciences, Davangere \\ ${ }^{3}$ Professor and Head, Department of Periodontics, College of Dental Sciences, Davangere
}

\begin{abstract}
Infection control is simple yet highly rewarding in terms of mental satisfaction to cure the patient of his problems by following proper infection control methods.The control of cross-infection and crosscontamination in dental practice is the focus of continuing discussion and debate and, as a result, recommendations and guidelines are regularly reviewed in the light of available information. To minimise the risk of transmission of infection between patients and between patients and Health Care Workers (HCW's) a sensible and practical routine for the prevention of cross-contamination and cross-infection should be followed. The present review article highlights various vast aspects of infection control, preventive protocols and recommendations to be followed in dental settings which include CDC (Centre for Disease Control, USA) and the Hospital Infection Control Practise Advisory Committee (HICPAC) standard Precautions, The OSHA (Occupational Safety and Health Administration) USA regulations, Work restrictions for dental health care personnel, Management of exposure to blood and body fluids, Evaluation of infection control program, Infection control considerations in dental office design.
\end{abstract}

Keywords :- Centers for Disease Control and Prevention (U.S.), Cross Infection, Infection Control, United States Occupational Safety and Health Administration

\section{Introduction}

Ignaz Semmelweis, a Hungarian physician (1818-1865), now regarded as the 'father of infection control,' first demonstrated that doctors were causing deaths by not washing their hands prior to patient examinations. ${ }^{1}$ Cross- infections contribute to unsafe care which is responsible for a great deal of mortality and morbidity globally. ${ }^{2}$ It was not until the recognition of the risk associated with the hepatitis B virus (HBV) in 1970s and the human immuno- deficiency virus (HIV) in 1980s, the dental profession embraced the fundamentals of infection control seriously. ${ }^{3-5}$ For several years, immersion of instruments in boiling water was the method of choice for decontamination of instruments. ${ }^{5}$ The recommendations, such as the 'universal precautions' or 'standard precautions' accelerated the widespread use of gloves as barriers by dental professionals. ${ }^{4}$ The British Dental Association (BDA) in 1986 and Center for Disease Control (CDC) in the USA in 1987 recommended the universal precautions for the prevention if blood borne infections. A reported case of suspected transmission of HIV from an infected dentist in the UK prompted the use of autoclaves in the UK in $1990 .{ }^{5}$ American Dental Association (ADA) in collaboration with the CDC developed guidelines for dental practices in 1993. ${ }^{6}$ The CDC updated the guidelines on the infection control measures for dental practice on several occasions and a comprehensive guidance for procedures in dental settings was made available in 2003; which was recommended by the ADA for all dental practices. ${ }^{6}$ It is observed that in the field of dentistry, adequate sterilization and disinfection appears to be the most neglected step due to a variety of reasons ranging primarily from lack of concern to finances. However the importance and need for the adequate sterilization in the light of various transmissible diseases and cross- contamination cannot be ignored. ${ }^{7}$ The dental professional has a legal and ethical responsibility to prevent infections in patients and staff members and an interest in protecting himself from contracting a disease from a patient ${ }^{8}$

Transmission of diseases in a dental setup occurs in various routes like from the patient to the dental team,from the dental worker to the patient, from one patient to another,from dental office to community,from community to patient. ${ }^{9}$ In the dental setting, possible modes of transmission in the order of severity are ${ }^{10}$ Percutaneous (high risk), Contact (high risk), Inhalation of Aerosols or droplets containing pathogens (moderate risk),Indirect contact through fomites (low risk). Thus the rationale for infection control in dental healthcare system is to "control" iatrogenic, nosocomial infections among patients ${ }^{11}$, and potential occupational exposure of dental health care personnel to disease causing microbes during provision of dental care.

Infection control refers to a comprehensive, systematic program that, when applied prevents the transmission of infectious agents among persons who are in direct or indirect contact with the healthcare environment.The purpose of infection control in dental practice is to prevent the transmission of diseaseproducing agents such as bacteria, viruses and fungi from one patient to another patient, from dental practitioner and dental staff to patients, and from patients to dental practitioner or other dental staff.Infection control focuses 
on limiting or controlling factors that influence the transmission of infection or that contribute to the spread of microorganisms.

In 1996 CDC (Centre for Disease Control, USA) and the Hospital Infection Control Practise Advisory Committee (HICPAC) introduced Standard Precautions. There are two levels of infection control precautions:

1. Standard precautions which are applied to all patients.

2.Transmission based precautions which are additional to standard precautions for certain 'at risk' patient groups.

\section{1 standard precautions}

Standard precautions are the practices and procedures that integrate and expand the elements of universal precautions into a standard of care intended to protect healthcare workers and patients from pathogens that can be spread by blood or any other body fluids (except sweat), regardless of whether they contain blood. This term applies to contact with blood, all body fluids, all body secretions and excretions, non-intact skin, and mucous membranes. The concept of standard precautions has been a cornerstone of dental infection control since the mid-1980s. Encompassing a set of infection control and safety procedures intend to protect against bloodborne disease transmission.For in-patient settings like hospitals, standard precautions expanded the set of infection control procedures required for safe patient care.

\section{Standard precautions include:}

1.Medical History

2.Hand Hygiene

3.Personal Protective Equipment

For dental personnel

- Gloves and Gloving

- Masks, Faceshields

- Protective clothing

For patient

- Protective eyewear

- Protective draping

4. Personnel immunization

5. Minimization of spatter

6. Surface barriers

7. Surface disinfection

8. Instrument reprocessing and sterilization monitoring

- Holding (presoaking)

- Cleaning and decontamination

- Packaging

- Sterilization

- common methods of sterilization

- sterilization monitoring

- $\quad$ Storage of instruments

9) Dental unit water contamination control

10) Radiographic asepsis

11. Dental laboratory asepsis

12. Asepsis of electronic and other devices

- lasers

- curing light

- implants etc

13. Management of dental wastes

14. Correct handling and disposal of needles and sharps

\subsubsection{Medical history}

At the patient's initial appointment, the dentist must obtain a thorough and relevant medical history of the patient. This history must be reviewed and if necessary updated at subsequent visits as appropriate ${ }^{11,12} \mathrm{~A}$ complete medical history should always be obtained. Specific questions about lymphadenopathy, recent weight loss, and infections should be included. All positive responses should be followed up. An individual may not be aware of an infectious state, so diagnostic acumen may be required. ${ }^{13}$ 


\subsubsection{Hand hygiene}

Hand hygiene is a general term applying to processes aiming to reduce the number of microorganisms on hands. Hand hygiene is important type of personal hygiene for everyone but is a primary disease prevention procedure for healthcare worker in dentistry and medicine. Transient flora, which colonize the superficial layers of the skin, are easier to remove by routine handwashing. Hand hygiene (e.g., handwashing, hand antisepsis, or surgical hand antisepsis) substantially reduces potential pathogens on the hands and is considered the single most critical measure for reducing the risk of transmitting organisms to patients and health care personnel. Noncompliance with hand hygiene practices is associated with health care associated infections, spread of multiresistant organisms and a major contributor to outbreaks.Persistence, cost per use, supply, possible allergies, compatibility with lotions used are the characteristics that must be considered before using a handwash.Common antimicrobial agents in hand hygiene products include alcohols (ethanol, isopropanol, propanol), chlorhexidine digluconate, iodophor, parachlorometaxylenol, triclosan and quarternary ammonium compounds(Table 1$)^{9}$. The preferred method for hand hygiene depends on the type of procedure, the degree of contamination, and the desired persistence of antimicrobial action on the skin(Table 1$)^{9}$. In the recent past, hand sanitizers that are alcohol based with or without other germicides hand sanitizers incorporated in wet-wipes have entered the market. These items are primarily for use when handwashing is impractical or cannot be done (nonavailability of water and antimicrobial handsoap).

\subsubsection{Personnel protective equipment:-}

\section{- Personnel protective equipment for dental personnel}

Personal Protective Equipment (PPE) includes the barriers that are used to prevent the exposure to microorganisms escaping from their sources.PPE use is determined by the anticipated exposure to blood or other potentially infectious material (BOPIM) and chemical hazards. Use of "full PPE" (protective eyewear, mask, gown and gloves) is needed when there is a potential for splash or spatter (use of air/water syringe, high speed handpiece and/or scalers), or a potential for exposure to chemicals that can splash/spatter on the face or mucosa. The main use of barriers is to control gross contamination and not prevent spread of every single microbe. PPE commonly used in general dental care are single-use-disposable gloves (sterile or non-sterile), protective eyewear, face-shields, masks, gowns and utility gloves used to protect personnel from blood and body fluids and chemical hazards. ${ }^{14}$

\section{Gloves}

Gloves protect dental team members from direct contact with microorganisms present in patient's mouth and on contaminated surfaces and chemicals like disinfectants ,dental materials, x-ray developing solutions etc as small cuts and abrasions on hands can act as portal of entry of microbes into the body.Gloving can prevent saliva and blood impaction in these difficult to clean areas and prevent cross contamination to subsequent patients and other team members. Microbes present in blood of dentist can exit body through cuts in skin can cause diseases like hepatitis to patient if gloves are not worn.

Gloves may be categorized according to

a) Use for patient care- 1) Single-use-disposable non-sterile exam gloves,

2) Single-use-disposable sterile surgical gloves, 3)Utility gloves, 4)Over gloves or food handlers gloves

b) Material (Fig 1) ${ }^{11}$ - 1)Latex, 2)Non latex:neoprene,block copolymer.vinyl,N-nitryl

Masks

It is a type of PPE that is worn over the nose and mouth to protect dental health care personnel's respiratory mucosa from inhaling infectious organisms spread by the aerosol spray of the handpiece or air-water syringe and by accidental splashes or sprays of blood or body fluids. ${ }^{15}$ Masks do not confer complete microbiological protection but they do stop potentially contaminated droplet splatter from contaminating the face. A mask should have at least 95 percent filtration efficiency for particles 3 to 5 micrometers $(\mu \mathrm{m})$ in diameter ${ }^{10}$.The two most common types of masks (Fig 2$)^{16}$ are the a)Domeshaped, b) Flat type

\section{Eye protection}

It is a type of PPE which is worn to protect the eyes from foreign bodies, aerosolized pathogens such as herpes simplex viruses and Staphylococcus, spatter or debris generated during dental procedures especially during scaling (manual and ultrasonic), the use of rotary instruments, cutting and use of wires and the cleaning of instruments, splattered solutions and caustic chemicals. The two types of protective eyewear (Fig 3$)^{16}$ used during patient care are: (1) glasses with protective side shields, (2) clear face shields ${ }^{16}$. A chin-length plastic 
face shield may be worn as an alternative to protective eyewear but it cannot replace a face mask due to its unability to protect against inhalation of contaminated aerosols ${ }^{16}$.

\section{Protective clothing}

It is the type of PPE that covers personal clothing and skin likely to be soiled with blood, saliva, or other potentially infectious materials. It includes a reusable or disposable gown, laboratory coat, or uniform. It can be : a)long sleeved (Fig 4) ${ }^{10}$, b)short sleeved

\section{Headcap}

Hair should be kept back out of the treatment field because they can trap heavy contamination. DHCP should protect their head with a surgical cap when probability of encountering heavy spatter is there e.g. from ultrasonic scaling device.

\section{Footwear}

Closed-in, non-slip flat shoes must be worn at all times when in any clinical or laboratory area ${ }^{17}$.

\section{- Personnel protection equipment for patient :}

Eye protection ${ }^{15}$, Protective draping

\subsubsection{Minimization of spatter}

All procedures involving blood or saliva should be performed in a way to minimize spraying, splashing, spattering and generation of droplets. It includes use of: Rubber Dam, High volume evacuation ${ }^{18}$, Preprocedural mouthrinse ${ }^{19}$

\subsubsection{Personnel immunization}

Immunizations substantially reduce the number of dental health care personnels susceptible to infectious diseases, as well as the potential for disease transmission to other staff and patients. Therefore, immunizations are an essential part of infection prevention and control programs(Table 2) ${ }^{19}$. If the clinicians live in endemic areas of Cholera, or travel frequently to endemic areas of Cholera, the clinicians should be vaccinated against cholera. ${ }^{12}$ Hepatitis A viral infection immunization is advised but not recommended for those not protected. Rubella and Rubeola must not be given to immunocompromised persons. Booster doses are not required for mumps. If a health care worker who is immunized against polio is exposed to the oral secretions of a patient with active polio, oral polio vaccine (live attenuated virus) or inactivated polio virus vaccine boosters are needed.

\subsubsection{Surface barriers}

Clinical contact surfaces can be directly contaminated from patient materials either by direct spray or spatter generated during dental procedures or by contact with dental health care personnel's gloved hands. Surface barriers are a practical and an easy way to contain cross-contamination. Barriers can be sterile or nonsterile depending on whether they are used for a surgical or a non-surgical routine dental care. Barrier protection of surfaces and equipment can prevent contamination of clinical contact surfaces, but is particularly effective for those that are difficult to clean. Barriers include clear plastic wrap, bags, sheets, tubing, and plastic-backed paper or other materials impervious to moisture. Because such coverings can become contaminated, they should be removed and discarded between patients, while DHCP are still gloved. After removing the barrier, the surface should be examined to make sure that it is not become soiled inadvertently. The surface needs to be cleaned and disinfected only if contamination is evident. Otherwise, after removing gloves and performing hand hygiene, DHCP should place clean barriers on these surfaces before the next patient ${ }^{9,20,21}$.

\subsubsection{Disinfection}

Between clinical sessions all work surfaces including those apparently uncontaminated (outside zoned area), should be thoroughly cleaned and decontaminated with detergent and a suitable viricidal disinfectant. Housekeeping surfaces, such as floors and walls, have a limited risk of disease transmission. Accordingly, these surfaces usually require only periodic cleaning with dilute detergents.

If a surface is suspected to have become contaminated with blood, saliva or other bodily fluids, it should be cleaned first by applying a detergent liquid to the surface and physically wiping the area and then disinfected with an appropriate low-level disinfectant (e.g. household bleach diluted 1:50 or accelerated hydrogen peroxide) that will destroy or deactivate all microbes ${ }^{20}$. Patient-care items (dental instruments, devices, and equipment) are 
categorized as critical, semicritical, or noncritical ${ }^{22}$, depending on the potential risk for infection associated with their intended use with critical and semicritical being high risk and noncritical being low risk devices.

Three levels of disinfection, high, intermediate, and low, are used for patient-care devices that do not require sterility and two levels, intermediate and low, for environmental surfaces(Table 3) ${ }^{19}$. Other than sterilants and disinfectants other chemicals used are: Antiseptic germicides which include active chlorine dioxide germicides ,essential oil compounds, iodinated, compounds, chlorhexidine compounds, cetylpyridium compounds , sanguinarine based compounds and parachlorometaxylenol compounds etc. Different types of disinfection are Thermal disinfection using washer-disinfectors and Chemical disinfection using instrument disinfectants Different types of disinfectants are Immersion disinfectants, Surface disinfectants , Alcohol based disinfectants ${ }^{11}$, Water based disinfectants

Disinfectants can be dispensed as foams, alcohol based aerosol sprays, alcohol based pump sprays, water-based pump sprays or towelettes that are saturated with a disinfectant (may be water based or alcohol base).

\subsubsection{Instrument reprocessing}

Instrument reprocessing is the most important aspect of Dental Infection Control as it deals with items that have the greatest potential for disease transmission during dental care. Any dental instrument that enters the oral cavity is classified as critical or semi critical surfaces as per Spaulding's Classification and must be sterilized or sterile-single-use disposables should be used.Common methods of in-office sterilization in dentistry are Autoclaving, Chemiclaving and Dry Heat. For items that are heat labile chemical immersion methods using an approved chemical sterilant must be used.

Steps in instrument reprocessing include:-

- Holding(presoaking)

- Cleaning,decontamination

- Packaging of instruments -Packaged sterile instruments can be stored for as long as the integrity of the pouch/package is not broken, damaged or affected by moisture after being sterilized and dried.

- Methods of sterilization

Common methods of sterilization in dentistry are : a) Autoclave or steam under pressure, b) Chemiclave or combination of synergistic chemicals, heat and pressure, c) Dry Heat.

Items sterilized by heat are: (a) All hand and orthodontic instruments (b) All burs and bur changers, including contaminated laboratory burs and diamond abrasives (c) All endodontic instruments (d) Air-water syringe tips (e) High-volume evacuator tips (f) Surgical instruments (g)Ultrasonic periodontal scalers and tips (h) Electrosurgery tips (i) Metal impression trays (j) Intra-oral radiographic equipment that can withstand heat sterilization. Autoclave- Autoclaving or sterilization using steam and pressure is by the most common method of sterilization. This is the most reliable process but can be more corrosive than the other methods for instruments that have a high content of carbon steel (especially if packages are not adequately dried). Items such as water (liquids) are sterilized other than regular instrument.

Chemiclaving - Chemiclaves use a combination of liquid chemicals (with $<15 \%$ water) that are introduced into the chamber, heat and pressure for a sterilization cycle. The parameters for sterilization are temperature of $131^{\circ} \mathrm{C}\left(270^{\circ} \mathrm{F}\right), 20 \mathrm{psi}$ and sterilization time of 30 minutes. Unsaturated chemical-vapor sterilization involves heating a chemical solution of primarily alcohol with $0.23 \%$ formaldehyde in a closed pressurized chamber.

Dry Heat - Dry heat is another common method of sterilization in dentistry. Although dry heat has the advantages of low operating cost and being noncorrosive, it is a prolonged process and the high temperatures required are not suitable for certain patient-care items and devices Dry-heat sterilizers used in dentistry include static-air ${ }^{19}$ and forced-air types.

\section{Sterilization of Unwrapped Instruments ${ }^{19}$}

An unwrapped cycle (sometimes called flash sterilization) is a method for sterilizing unwrapped patient-care items for immediate use. The time required for unwrapped sterilization cycles depends on the type of sterilizer and the type of item (i.e., porous or nonporous) to be sterilized.

Sterilization Monitoring. : Monitoring of sterilization procedures should include a combination of process parameters, including mechanical, chemical, and biological.These parameters evaluate both the sterilizing conditions and the procedure's effectiveness.

Mechanical techniques for monitoring sterilization include assessing cycle time, temperature and pressure by observing the gauges or displays on the sterilizer and noting these parameters for each load. Chemical indicators, internal and external, use sensitive chemicals to assess physical conditions (e.g. time and temperature) during the sterilization process. External indicators applied to the outside of a package (e.g., chemical indicator tape or special markings) change colour rapidly when a specific parameter is reached, and they verify that the package has been exposed to the sterilization process. Internal chemical indicators whether single or multiple parameter should be used inside each package to ensure the sterilizing agent has penetrated 
the packaging material and actually reached the instruments inside. If either mechanical indicators or internal/external chemical indicators indicate inadequate processing, items in the load should not be used until reprocessed.Biological indicators (BIs) (i.e., spore tests) are the most accepted method for monitoring the sterilization process because they assess it directly by killing known highly resistant microorganisms (e.g., Geobacillus or Bacillus species), rather than merely testing the physical and chemical conditions necessary for sterilization. Other methods of sterilization are : Ethylene oxide gas (ETO), Bead sterilizers ${ }^{23}$

Storage of Sterile Instruments : Sterile bagged instruments must be stored in clean dust-free shelves or cabinets.

\subsubsection{Dental water unit contamination control}

Microbial control of dental treatment water/irrigant contamination is a two pronged issue. Firstly, the dental unit water system should be cleaned and kept free of biofilms and other inorganic contaminants by initially and frequent periodic cleaning/disinfecting the system with a decontaminating agent(Table 4) ${ }^{11}$. Secondly, the water/irrigant used for patient care must be microbe-free, and therefore, the water needs to be filtered, sterile, and distilled/boiled or an EPA registered and FDA approved low-grade antimicrobial added prior to use.After each patient, water and air should be discharged for at least 20 to 30 seconds from any device that is connected to the dental water system and that enters the patient's mouth. (Such devices include handpieces, ultrasonic scalers, and air/ water syringes ${ }^{20}$. Sterile solutions (e.g., sterile saline or sterile water) should be used as a coolant/irrigation in the performance of oral surgical procedures ${ }^{16}$

\subsubsection{Radiographic asepsis}

When taking radiographs, the potential to cross-contaminate equipment and environmental surfaces with blood or saliva is high if aseptic technique is not practiced. Although oral and maxillofacial radiology (OMR) procedures fall mainly in the semicritical and non-critical categories of Spaulding's Classification of inanimate objects, many contagious diseases such as infectious mononucleosis and hepatitis-B can possibly be spread by simple contact with saliva. Therefore, whenever a potential for contamination by saliva exists during any OMR procedure, universal precautions must be observed including the use of adequate personal protective equipment (PPE) such as gloves ${ }^{11}$, the proper handling of contaminated materials, and the decontamination of surfaces exposed to saliva or contaminated materials. Care should be taken to avoid placing or removing a lead apron with contaminated gloves. Overgloves should be used or degloving followed by hand hygiene should be done ${ }^{20}$. Manufacturers should be consulted regarding appropriate barrier and disinfection/sterilization procedures for digital radiography sensors, other high-technology intraoral devices, and associated hardware ${ }^{12,24}$. Protective plastic pouches for radiographic films (Fig 5$)^{22}$

\subsubsection{Dental laboratory asepsis}

Items that are commonly used in a dental laboratory dentures, partials, impressions, bite registrations) are potential sources of cross-contamination. Dental prostheses or impressions can be contaminated with bacteria, viruses, and fungi. These items should be handled in a manner to prevent exposure to dental team members, patients, and the office environment. Extracted teeth that are to be used in the dental laboratory for shade-matching, in research and in materials testing laboratories, or in the preclinical laboratory for practicing cutting/restorative procedures or for preclinical examination must be decontaminated. Laboratory items (e.g., burs, polishing points, rag wheels, laboratory knives) that have been used on contaminated appliances or prostheses should be heat-sterilized, disinfected between patients, or discarded (disposable products). If manufacturers' instructions are unavailable, heat-stable items should be cleaned, sterilized and disinfected with an EPA-registered hospital disinfectant with low- to intermediate-level activity.(Table 5) ${ }^{11}$

\subsubsection{Asepsis of electronic and other equipments}

Lasers- Electrosurgical procedures tend to burn the tissue creating smoke and other possible byproducts .These gases/smoke/plumes contain chemicals like hydrogen cyanide, benzene and formaldehyde, and issue debris, microbes and viruses like Staphylococcus, Corynebacterium, Neisseria, Human papilloma virus and HIV affecting both the dental care providers and the patients . To control risks from electrosurgical and laser plumes dental health care personnel should wear full PPE including well fitting (tight face-fit) high filtration masks, face shields/goggles/protective eyewear, gloves, and fluid resistant gowns. A high volume evacuation system suction as close as possible to the site generating the gases/smoke/plumes must be used to control release of the gases/smoke/plumes into the ambient air and methods of improving air circulation in the clinic should also be used ${ }^{11,12,20}$

Curing light - Curing light tips are semi-critical pieces of equipment and should be heat sterilized or have an appropriate barrier placed over the tip for each patient which protect the sensitive light-conducting rods from accidental damage or material contamination. 
Implants- In the surgical procedures involved in the placement of implants both the instruments used and the implants must be sterile at the time of use. Full aseptic procedures with sterile fields must be employed. Explanted devices must not be reprocessed and reused ${ }^{19}$.

\subsubsection{Management of dental waste}

Biomedical waste is classified as hazardous waste and must not be disposed with regular garbage.In general, all biomedical waste must be stored in colour-coded containers that are marked with the universal biohazard symbol and released to an approved biomedical waste carrier for disposal.Biomedical waste can be further divided into Anatomical and Non-anatomical waste.With respect to dentistry waste material is classified as Regulated waste and Non-regulated waste

\subsubsection{Management of needles and sharps}

Inoculation injuries are the most likely route for transmission of blood borne viral infections in dentistry ${ }^{25}$. An exposure that might place health care staff at risk for HBV, HCV, or HIV infection may be a percutaneous injury (e.g., a needle stick or cut with a sharp object) or contact of mucous membrane or non intact skin e.g., (exposed skin that is chapped, abraded, or afflicted with dermatitis) with blood, tissue, or other body fluids that are potentially infectious. Measures to prevent needlestick injuries include avoiding resheathing of needles if possible, by using safe needle system and using single-hand resheathing of needles (Bayonet Technique) or using artery forceps, avoiding handling sharp instruments by the working end etc.

\subsection{Ttransmission based precautions}

For patients who present diseases that are transmitted through airborne, droplet, or contact transmission, standard precautions should be coupled with expanded or transmission-based precautions(Table $6)^{16}$

\subsection{1 work restrictions for dental health care personnel}

DHCP should be responsible for monitoring their own health status. If dental health care personnels have acute or chronic medical conditions rendering them susceptible to opportunistic infection, it should be discussed with their personal physicians whether the condition can affect their ability to safely perform their duties. Under certain circumstances, dental health care personnel should be excluded from work health-care facility managers from work or patient contact to prevent further transmission of infection. Decisions concerning work restrictions are based on the mode of transmission and the period of infectivity of the disease.(Table 7$)^{19}$

\subsection{2 management of exposure to blood and body fluids}

Postexposure management is important to prevent infection after an occupational exposure to blood. During dental procedures, saliva is predictably contaminated with blood . Even when blood is not visible, it can still be present in limited quantities and therefore is considered a potentially infectious material. Any occupational exposure incident to blood or OPIM, including saliva, regardless of whether blood is visible, in dental settings should be evaluated by dental health care personnel ${ }^{19}$.

\subsection{3evaluation of infection control program}

The goal of a dental infection-control program is to provide a safe working environment that will reduce the risk of healthcare associated infections among patients and occupational exposures among dental health care personnel. Effective program evaluation is a systematic way to ensure procedures are useful, feasible, ethical, and accurate ${ }^{19}$. Program evaluation is an essential organizational practice, however, such evaluation is not practiced consistently across program areas, nor is it sufficiently well-integrated into the dayto-day management of the majority of programs.(Table 8$)^{9}$

\subsection{4 infection control considerations in dental office design}

In the dental operatory, environmental surfaces (i.e., a surface or equipment that does not contact patients directly) can become contaminated during patient care. Certain surfaces, especially ones touched frequently (e.g., light handles, unit switches, and drawer knobs) can serve as reservoirs of microbial contamination, although they have not been associated directly with transmission of infection to either DHCP or patients. Although hand hygiene is key to minimizing the transfer of these micro organisms, barrier protection or cleaning and disinfecting of the environmental surfaces also protects against health care associated infections. Strategies for cleaning and disinfecting surfaces in patient-care areas should consider the 1) potential for direct 
patient contact; 2) degree and frequency of hand contact; and 3) potential contamination of the surface with body substances or environmental sources of microorganisms (e.g., soil, dust, or water). Carpeting is more difficult to clean than nonporous hard surface flooring, and it cannot be reliably disinfected, especially after spills of blood and body substances. Studies have documented the presence of diverse microbial populations, primarily bacteria and fungi, in carpeting. Cloth furnishings pose similar contamination risks in areas of direct patient care and places where contaminated materials are managed (e.g., dental operatory, laboratory or instrument processing areas). For these reasons, use of carpeted flooring and fabric-upholstered furnishings in these areas should be avoided ${ }^{26}$

The OSHA (Occupational Safety and Health Administration) in USA has summarized the following regulations for infection control in a dental practice ${ }^{27}$. Immunization to the employees within 10 days of employment especially Hepatitis B vaccination. Universal precautions must be observed to prevent contact with blood and other potentially infectious materials. Saliva is considered to be a blood contaminated body fluid in relation to dental treatment. Implementation of engineering controls to reduce production of contaminated spatter, mists and aerosols. Work practice control precautions to minimize splashing, spatter or contact of bare hands with contaminated surfaces. Provision of facilities and instructions for washing hands after removing gloves and for washing skin immediately or as soon as feasible after contact with blood or potentially infectious materials. Safe handling of needles and other sharp instruments. Encouragement of use of disposable or single use needles, wires, carpules and sharps as close to the place of use as possible. These must be disposed as soon as feasible in hard walled leak proof containers that are closable. The containers must bear a biohazard label. Teeth must be discarded into sharps containers. Contaminated reusable sharp instruments must not be stored or processed in a manner that requires the employees to use their hands. Prohibit eating, drinking, storage of food and handling contact lenses etc. in contaminated environments. Provision of personal protective items (like gloves, gowns etc) for staff including instructions for its usage. The staff should correctly use and discard or reuse the personal protective items. Soon after treatment, the house keeping requirements should be attended to, like the cleaning of floors and sinks that may be subjected to contamination. Provision of written schedule for cleaning must be made. Provision of laundering of protective garments used for universal precautions by the staff

II. Tables

\begin{tabular}{|c|c|c|c|c|}
\hline Method & Agent & Purpose & Duration & Indication \\
\hline Routine handwash & $\begin{array}{l}\text { Water and non } \\
\text { antimicrobial soap (e.g., }\end{array}$ & $\begin{array}{l}\text { Remove soil and } \\
\text { transient micro- } \\
\text { organisms }\end{array}$ & $15 \mathrm{sec}$ & $\begin{array}{l}\square \text { Before and } \\
\text { after treating each patient } \\
\text { (e.g., before glove } \\
\text { placement and after } \\
\text { glove removal). } \\
\square \quad \text { After } \\
\text { barehanded touching of } \\
\text { inanimate objects likely } \\
\text { to be contaminated by } \\
\text { blood or saliva. } \\
\square \\
\text { leaving the dental } \\
\text { operatory or the dental } \\
\text { laboratory. } \\
\square \text { When visibly } \\
\text { soiled. Before } \\
\square \text { regloving. } \\
\square \text { After } \\
\text { removing gloves that are } \\
\text { torn, cut, or punctured. }\end{array}$ \\
\hline $\begin{array}{l}\text { Antiseptic } \\
\text { handwash }\end{array}$ & plain soap & $\begin{array}{l}\text { Remove or destroy } \\
\text { transient } \\
\text { microorganisms }\end{array}$ & $15 \mathrm{sec}$ & \\
\hline Antiseptic handrub & $\begin{array}{l}\text { Water and antimicrobial } \\
\text { soap (e.g., }\end{array}$ & $\begin{array}{l}\text { reduce resident } \\
\text { flora }\end{array}$ & $\begin{array}{l}\text { Rub hands } \\
\text { until the } \\
\text { agent is dry }\end{array}$ & \\
\hline
\end{tabular}

Table 1. Hand-hygiene methods and indications ${ }^{9}$

\begin{tabular}{|c|c|c|c|c|}
\hline Vaccine & Dose schedule & Indications & $\begin{array}{l}\text { Major precautions and } \\
\text { contraindications }\end{array}$ & $\begin{array}{l}\text { Special } \\
\text { considerations }\end{array}$ \\
\hline $\begin{array}{l}\text { Hepatitis B } \\
\text { recombinant } \\
\text { vaccine }\end{array}$ & $\begin{array}{l}\text { Three-dose } \\
\text { schedule } \\
\text { administered } \\
\text { intramuscularly } \\
\text { (IM) in the }\end{array}$ & $\begin{array}{l}\text { Health-care personnel } \\
\text { (HCP) } \\
\text { at risk for exposure to } \\
\text { blood } \\
\text { and body fluids. }\end{array}$ & $\begin{array}{l}\text { History of anaphylactic } \\
\text { reaction to common } \\
\text { baker's } \\
\text { Pregnancy } \\
\text { is not a contraindication. }\end{array}$ & $\begin{array}{l}\text { No therapeutic or } \\
\text { adverse effects on } \\
\text { hepatitis } \\
\text { B virus (HBV)- } \\
\text { infected persons; cost }\end{array}$ \\
\hline
\end{tabular}




\begin{tabular}{|c|c|c|c|c|}
\hline & $\begin{array}{l}\text { deltoid; } 0,1,6 \text { - } \\
\text { second dose } \\
\text { administered } 1 \\
\text { month after first } \\
\text { dose; third dose } \\
\text { administered } 4 \\
\text { months after } \\
\text { second. Booster } \\
\text { doses are not } \\
\text { necessary for } \\
\text { persons who have } \\
\text { developed } \\
\text { adequate } \\
\text { antibodies } \\
\text { to hepatitis B } \\
\text { surface antigen } \\
\text { (anti-HBs). }\end{array}$ & & & 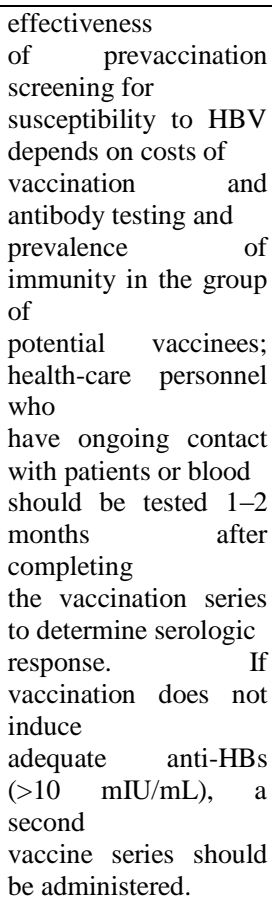 \\
\hline $\begin{array}{l}\text { Influenza } \\
\text { vaccine } \\
\text { (inactivated) }\end{array}$ & $\begin{array}{l}\text { Annual single- } \\
\text { dose vaccination } \\
\text { IM with current } \\
\text { vaccine. }\end{array}$ & $\begin{array}{l}\text { HCP who have contact } \\
\text { with } \\
\text { patients at high risk or } \\
\text { who } \\
\text { work in chronic-care } \\
\text { facilities; } \\
\text { HCP aged > } 50 \text { years or } \\
\text { who } \\
\text { have high-risk medical } \\
\text { conditions. }\end{array}$ & $\begin{array}{l}\text { History of anaphylactic } \\
\text { hypersensitivity } \\
\text { to eggs or to other } \\
\text { components } \\
\text { of the vaccine. }\end{array}$ & $\begin{array}{l}\text { Recommended for } \\
\text { women who will be in } \\
\text { the } \\
\text { second or third } \\
\text { trimesters of } \\
\text { pregnancy during } \\
\text { the influenza season } \\
\text { and women in any } \\
\text { stage } \\
\text { of pregnancy who } \\
\text { have chronic medical } \\
\text { conditions that are } \\
\text { associated with an } \\
\text { increased risk of } \\
\text { influenza }\end{array}$ \\
\hline $\begin{array}{l}\text { Measles } \\
\text { livevirus } \\
\text { Vaccine }\end{array}$ & $\begin{array}{l}\text { One dose } \\
\text { administered } \\
\text { subcutaneously } \\
\text { (SC); second } \\
\text { dose >4 weeks } \\
\text { later. }\end{array}$ & $\begin{array}{l}\text { HCP who were born } \\
\text { during or } \\
\text { after } 1957 \text { without } \\
\text { documentation } \\
\text { of } 1 \text { ) receipt of } 2 \text { doses of } \\
\text { live vaccine on or after } \\
\text { their first } \\
\text { birthday, 2) physician- } \\
\text { diagnosed } \\
\text { measles, or 3) laboratory } \\
\text { evidence of immunity. } \\
\text { Vaccine } \\
\text { should also be considered } \\
\text { for } \\
\text { all HCP who have no } \\
\text { proof of } \\
\text { immunity, including } \\
\text { those born } \\
\text { before } 1957 \text {. }\end{array}$ & $\begin{array}{l}\text { Pregnancy; } \\
\text { immunocompromised } \\
\text { state (including human } \\
\text { immunodeficiency } \\
\text { virus [HIV]-infected } \\
\text { persons with severe } \\
\text { immunosuppression); } \\
\text { history of anaphylactic } \\
\text { reactions after gelatin } \\
\text { ingestion or } \\
\text { receipt of neomycin; or } \\
\text { recent receipt of antibody- } \\
\text { receipt } \\
\text { containing } \\
\text { blood products }\end{array}$ & $\begin{array}{l}\text { Measles, mumps, } \\
\text { rubella (MMR) is the } \\
\text { recommended vaccine, } \\
\text { if recipients are also } \\
\text { likely to be susceptible } \\
\text { to rubella or mumps; } \\
\text { persons vaccinated } \\
\text { during 1963-1967 } \\
\text { with } \\
\text { 1) measles killed-virus } \\
\text { vaccine alone, } \\
\text { 2) killed-virus vaccine } \\
\text { followed by live-virus } \\
\text { vaccine, or } \\
\text { 3) a vaccine of } \\
\text { unknown type, } \\
\text { should be revaccinated } \\
\text { with two doses of } \\
\text { live-virus measles } \\
\text { vaccine. }\end{array}$ \\
\hline $\begin{array}{l}\text { Mumps } \\
\text { livevirus } \\
\text { Vaccine }\end{array}$ & $\begin{array}{l}\text { One dose SC; no } \\
\text { booster }\end{array}$ & $\begin{array}{l}\text { HCP believed susceptible } \\
\text { can } \\
\text { be vaccinated; adults } \\
\text { born } \\
\text { before } 1957 \text { can be } \\
\text { considered } \\
\text { immune. }\end{array}$ & $\begin{array}{l}\text { Pregnancy; } \\
\text { immunocompromised } \\
\text { state; history of } \\
\text { anaphylactic } \\
\text { reaction after gelatin } \\
\text { ingestion or } \\
\text { receipt of neomycin. }\end{array}$ & $\begin{array}{l}\text { MMR is the } \\
\text { recommended vaccine }\end{array}$ \\
\hline $\begin{array}{l}\text { Rubella } \\
\text { livevirus } \\
\text { Vaccine }\end{array}$ & $\begin{array}{l}\text { One dose SC; no } \\
\text { booster. }\end{array}$ & $\begin{array}{l}\text { HCP, both male and } \\
\text { female, } \\
\text { who lack documentation } \\
\text { of }\end{array}$ & $\begin{array}{l}\text { Pregnancy; } \\
\text { immunocompromised } \\
\text { state; history of } \\
\text { anaphylactic }\end{array}$ & $\begin{array}{l}\text { Women pregnant when } \\
\text { vaccinated or who } \\
\text { become pregnant } \\
\text { within } 4 \text { weeks of }\end{array}$ \\
\hline
\end{tabular}




\begin{tabular}{|c|c|c|c|c|}
\hline & & $\begin{array}{l}\text { receipt of live vaccine on } \\
\text { or } \\
\text { after their first birthday, } \\
\text { or lack } \\
\text { of laboratory evidence of } \\
\text { immunity can be } \\
\text { vaccinated. } \\
\text { Adults born before } 1957 \\
\text { can } \\
\text { be considered immune, } \\
\text { except } \\
\text { women of childbearing } \\
\text { age. }\end{array}$ & $\begin{array}{l}\text { reaction after receipt of } \\
\text { neomycin }\end{array}$ & $\begin{array}{l}\text { vaccination should be } \\
\text { counseled regarding } \\
\text { theoretic risks to the } \\
\text { fetus; however, the } \\
\text { risk } \\
\text { of rubella vaccine- } \\
\text { associated } \\
\text { malformations } \\
\text { among these women is } \\
\text { negligible. MMR is the } \\
\text { recommended vaccine. }\end{array}$ \\
\hline $\begin{array}{l}\text { Varicella- } \\
\text { zoster } \\
\text { live-virus } \\
\text { vaccine }\end{array}$ & $\begin{array}{l}\text { Two } 0.5 \mathrm{ml} \text { doses } \\
\text { SC } 4-8 \\
\text { weeks apart if } \\
\text { aged }>13 \text { years. }\end{array}$ & $\begin{array}{l}\text { HCP without reliable } \\
\text { history of } \\
\text { varicella or laboratory } \\
\text { evidence } \\
\text { of varicella immunity. }\end{array}$ & $\begin{array}{l}\text { Pregnancy; } \\
\text { immunocompromised } \\
\text { state; history of } \\
\text { anaphylactic } \\
\text { reaction after receipt of } \\
\text { neomycin } \\
\text { or gelatin; recent receipt } \\
\text { of } \\
\text { antibody-containing } \\
\text { blood products; } \\
\text { salicylate use should be } \\
\text { avoided } \\
\text { for } 6 \text { weeks after } \\
\text { vaccination. }\end{array}$ & $\begin{array}{l}\text { Because } 71 \%-93 \% \text { of } \\
\text { U.S.-born persons } \\
\text { without a history of } \\
\text { varicella are immune, } \\
\text { serologic testing } \\
\text { before vaccination } \\
\text { might be } \\
\text { cost-effective. }\end{array}$ \\
\hline
\end{tabular}

Table 2-Different Vaccines Recommended For Dental Health Care Personnel ${ }^{19}$

\begin{tabular}{|c|c|c|c|c|c|}
\hline Process & Result & Method & Example & $\begin{array}{l}\text { Type of patient care } \\
\text { item }\end{array}$ & $\begin{array}{l}\text { Environmental } \\
\text { surfaces }\end{array}$ \\
\hline Sterilization & $\begin{array}{l}\text { Destroys all } \\
\text { microorganis } \\
\text { ms, } \\
\text { including } \\
\text { bacterial } \\
\text { spores. }\end{array}$ & $\begin{array}{l}\text { Heat- } \\
\text { automated } \\
\text { High } \\
\text { temperature } \\
\text { Low } \\
\text { Temperature } \\
\text { Liquid } \\
\text { immersion }\end{array}$ & $\begin{array}{l}\text { Steam, dry heat, } \\
\text { unsa-turated } \\
\text { chemical vapor } \\
\text { Ethylene oxide } \\
\text { gas, plasma } \\
\text { sterilization } \\
\text { Chemical } \\
\text { sterilants- } \\
\text { Glutaraldehyde, } \\
\text { glutaraldehydes } \\
\text { with phenol, } \\
\text { hydrogen } \\
\text { peroxide, } \\
\text { hydrogen peroxide } \\
\text { with peracetic } \\
\text { acid, peracetic acid } \\
\text { perid }\end{array}$ & $\begin{array}{l}\text { Heat-tolerant critical } \\
\text { and semicritical } \\
\text { Heat sensitive critical } \\
\text { and s emicritical } \\
\text { Heat sensitive critical } \\
\text { and semicritical }\end{array}$ & $\begin{array}{l}\text { Not } \\
\text { Applicable }\end{array}$ \\
\hline $\begin{array}{l}\text { High-level } \\
\text { Disinfection }\end{array}$ & $\begin{array}{l}\text { Destroys all } \\
\text { microorganis } \\
\text { ms, } \\
\text { but not } \\
\text { necessarily } \\
\text { high numbers } \\
\text { of bacterial } \\
\text { spores. }\end{array}$ & $\begin{array}{l}\text { Heat- } \\
\text { automated } \\
\text { Liquid } \\
\text { immersion }\end{array}$ & $\begin{array}{l}\text { Washer disinfecor } \\
\text { Chemical } \\
\text { sterilants/high- } \\
\text { level disinfectants. } \\
\text { Glutaraldehyde, } \\
\text { glutaraldehyde } \\
\text { with phenol, } \\
\text { hydrogen } \\
\text { peroxide, } \\
\text { hydrogen peroxide } \\
\text { with } \\
\text { peracetic acid, } \\
\text { ortho- } \\
\text { phthalaldehyde }\end{array}$ & $\begin{array}{l}\text { Heat sensitive } \\
\text { semicritical }\end{array}$ & Not applicable \\
\hline $\begin{array}{l}\text { Intermediat } \\
\text { elevel } \\
\text { disinfection }\end{array}$ & $\begin{array}{l}\text { Destroys } \\
\text { vegetative } \\
\text { bacteria } \\
\text { and } \\
\text { majority of } \\
\text { fungi and } \\
\text { viruses. } \\
\text { Inactivates }\end{array}$ & Liquid contact & $\begin{array}{l}\text { U.S. } \\
\text { Environmental } \\
\text { Protection Agency } \\
\text { (EPA)- } \\
\text { registered hospital } \\
\text { disinfectant with } \\
\text { label claim } \\
\text { of tuberculocidal }\end{array}$ & $\begin{array}{l}\text { Noncritical with } \\
\text { visible blood }\end{array}$ & $\begin{array}{l}\text { Clinical contact } \\
\text { surfaces; blood } \\
\text { spills on } \\
\text { housekeeping } \\
\text { surfaces }\end{array}$ \\
\hline
\end{tabular}




\begin{tabular}{|c|c|c|c|c|c|}
\hline & $\begin{array}{l}\text { Mycobacteriu } \\
\text { m bovis. Not } \\
\text { necessarily } \\
\text { capable of } \\
\text { killing } \\
\text { bacterial } \\
\text { spores. }\end{array}$ & & $\begin{array}{l}\text { activity (e.g., } \\
\text { chlorine } \\
\text { containing } \\
\text { products, } \\
\text { quaternary } \\
\text { ammonium } \\
\text { compounds with } \\
\text { alcohol, phenolics, } \\
\text { iodophors, } \\
\text { EPA-registered } \\
\text { chlorine-based } \\
\text { product } \\
\end{array}$ & & \\
\hline $\begin{array}{l}\text { Low-level } \\
\text { disinfection }\end{array}$ & $\begin{array}{l}\text { Destroys the } \\
\text { majority of } \\
\text { vegetative } \\
\text { bacteria, } \\
\text { certain } \\
\text { fungi, and } \\
\text { viruses. Does } \\
\text { not } \\
\text { inactivate } \\
\text { Mycobacteriu } \\
\mathrm{m} \\
\text { bovis. }\end{array}$ & Liquid contact & $\begin{array}{l}\text { EPA-registered } \\
\text { hospital } \\
\text { disinfectant with } \\
\text { no } \\
\text { label claim } \\
\text { regarding } \\
\text { tuberculocidal } \\
\text { activity. } \\
\text { The Occupational } \\
\text { Safety and Health } \\
\text { Administration } \\
\text { also requires label } \\
\text { claims of human } \\
\text { immunodeficiency } \\
\text { virus (HIV) and } \\
\text { hepatitis B } \\
\text { virus (HBV) } \\
\text { potency for } \\
\text { clinical contact } \\
\text { surfaces } \\
\text { (e.g., quaternary } \\
\text { ammonium } \\
\text { compounds, some } \\
\text { phenolics, some } \\
\text { iodophors) }\end{array}$ & $\begin{array}{l}\text { Non critical without } \\
\text { visible blood }\end{array}$ & $\begin{array}{l}\text { Clinical contact } \\
\text { surfaces; } \\
\text { housekeeping } \\
\text { surfaces }\end{array}$ \\
\hline
\end{tabular}

Table 3-Different Levels Of Disinfection ${ }^{19}$

\begin{tabular}{|l|l|}
\hline Some Periodic Cleaners & Method of Use \\
\hline Alkaline Peroxide - Sterilex Ultra & $\begin{array}{l}\text { Full strength, overnight contact followed by flushing with } \\
\text { hot water }\end{array}$ \\
\hline Chlorine Dioxide Tablets - Vista Tabs & $\begin{array}{l}30-50 \mathrm{ppm} \text { in water, 5-10 minutes followed by flushing } \\
\text { with water }\end{array}$ \\
\hline Chlorine Dioxide 2 part Liquid - BioClenz & $\begin{array}{l}30-50 \mathrm{ppm} \text { in water, 5-10 minutes followed by flushing } \\
\text { with water }\end{array}$ \\
\hline Electro-chemical Oxidants - Sterilox & $\begin{array}{l}\text { Full Strength 30 minutes - overnight contact, followed by } \\
\text { flush with dilute oxidant }\end{array}$ \\
\hline Silver Citrate Powder - specific to Pure Tube & $\begin{array}{l}\text { Dissolved in water with low total dissolved solids (TDS) and } \\
\text { left over night, followed by a water flush }\end{array}$ \\
\hline Peracetic Acid - TAED+Perborate (Italy/EU) & $\begin{array}{l}5-0 \text { minute between patients used in the Castellini Autosteril } \\
\text { System, followed by sterile water flush }\end{array}$ \\
\hline Some Irrigants & Method of Use \\
\hline Boiled water/Distilled/Sterile water & Directly in the bottle as irrigant \\
\hline Silver Nitrate Tablets - ICX & Dissolve in 700 ml of municipal water \\
\hline Silver Citrate Tablets - BluTabs & Dissolve in 700 ml of municipal water \\
\hline Silver - PureTube (Sterisil) & Silver ions in water with Low TDS \\
\hline Iodine - Dentapure (DP 40, 90 and 360) & $\begin{array}{l}\text { Used inside the bottle replacing the intake tube, or placed in } \\
\text { line with water flow (3-4 ppm) }\end{array}$ \\
\hline Chlorine Dioxide 2 part Liquid - BioClenz & $2-4$ ppm in municipal water \\
\hline Electro-chemical Oxidants - Sterilox & Concentrate diluted for irrigant purposes \\
\hline Grapefruit Extract Botanical - Vistaclean & 5 drops per 700 ml of municipal water (emulsifying agent) \\
\hline
\end{tabular}

Table 4-List Of Some Periodic Cleaners And Irrigants Being Used By Practitioners ${ }^{11}$

\begin{tabular}{|l|l|}
\hline Items for Decontamination & Decontamination Methods \\
\hline Impressions and stone casts & $\begin{array}{l}\text { Surface Disinfection or Immersion Disinfection followed } \\
\text { by rinsing in water }\end{array}$ \\
\hline Removable Prostheses, Bite- Registration/Blocks & $\begin{array}{l}\text { Surface Disinfection or Immersion Disinfection followed } \\
\text { by rinsing in water }\end{array}$ \\
\hline $\begin{array}{l}\text { Metal, Porcelain \& Porcelain Fused to Metal crowns } \\
\text { and Bridges }\end{array}$ & Ultrasonic Cleaning and Sterilization \\
\hline
\end{tabular}




\begin{tabular}{|c|c|}
\hline $\begin{array}{l}\text { Burs/Finishing/Polishing Burs/Discs, Garnet, Cuttle } \\
\text { etc. }\end{array}$ & Ultrasonic Cleaning and Sterilization \\
\hline $\begin{array}{l}\text { Compound/Green-Stick Compound for } \\
\text { border-molding }\end{array}$ & Unit-Dose per patient and discard the unused items \\
\hline $\begin{array}{l}\text { Hot-Water Bath/Tub for softening } \\
\text { compound during border molding }\end{array}$ & $\begin{array}{l}\text { Clean and disinfect after each patient (wait till it cools } \\
\text { down) }\end{array}$ \\
\hline Flame torch/Bunsen Burners etc. & Clean and disinfect after cool down \\
\hline Reusable metal impression trays & Cleaned, sonicated and sterilized \\
\hline Plastic impression trays & Discarded after one use \\
\hline Facebow & Sanitized and Disinfected \\
\hline Bite-Plane/Intra-oral Insert for Face Bow & Sanitized and Sterilized \\
\hline Articulators & Cleaned/Sanitized and Disinfected \\
\hline Rag-Wheels and Rotary Polishing Brushes & Ultrasonic cleaning and Sterilization at least once daily \\
\hline $\begin{array}{l}\text { All other devices including mixing bowls, wax } \\
\text { knifes, buffalo knife spatulas etc. }\end{array}$ & Sanitization, Disinfection and sterilization as needed \\
\hline Counter/Work Surfaces/Bench & $\begin{array}{l}\text { Use of a Disposable Brown Paper (Heavy Gauge) as lab } \\
\text { bench/ table/work-surface cover, disposed after use. Work } \\
\text { Surface sanitized and disinfected at the end of each day }\end{array}$ \\
\hline
\end{tabular}

Table 5-Some Methods Of Decontamination In The Dental Laboratory ${ }^{11}$

\begin{tabular}{|c|c|c|}
\hline $\begin{array}{ll} & \text { Di } \\
\text { sease } & \end{array}$ & Mode Of Transmission & Recommended Precautions \\
\hline Hepatitis A & Contact (Faecal-Oral Route) & $\begin{array}{l}\text { Standard Precautions For Continent } \\
\text { Patients } \\
\text { Additional Precautions For } \\
\text { Incontinent Patients - Single Room } \\
\text { With Ensuite Toilet Is Desirable }\end{array}$ \\
\hline Hepatitis B & $\begin{array}{l}\text { Parenteral ,Permucosal, Sexual } \\
\text { Contact, Prenatal }\end{array}$ & Hepatitis B Vaccine To All Health Care Personnel \\
\hline Hiv & $\begin{array}{l}\text { Sexual Contact,Exposure To Blood } \\
\& \text { Blood Contaminated Body } \\
\text { Fluids,Perinatalcontact }\end{array}$ & $\begin{array}{l}\text { Protection Of Dental Health Care Personnel From } \\
\text { Exposure To Blood,Saliva And Other Potentially } \\
\text { Infectious Body Fluids Of Patients And Prevention Of } \\
\text { Contact Of Blood And Body Fluids Of Dental Health } \\
\text { Care Personnel With Blood Of Patients+All Other } \\
\text { Standard Precautions }\end{array}$ \\
\hline $\begin{array}{l}\text { Herpes } \\
\text { Simplex }\end{array}$ & $\begin{array}{l}\text { Contact (Droplet Spread By Direct } \\
\text { Contact Or Indirectly By Fomites } \\
\text { Or } \\
\text { By Contact With Infectious Lesions }\end{array}$ & $\begin{array}{l}\text { Standard Precautions } \\
\text { Additional Precautions (Contact } \\
\text { Transmission) For Patients With Lesions } \\
\text { Disseminating Infectious Virus. } \\
\text { Hcws Should Cover Vesicular Lesions. } \\
\text { When Lesions Uncovered, Exclude } \\
\text { Hcw From Contact With Neonates Or } \\
\text { Immunocompromised Patients And } \\
\text { From Operating Rooms And Delivery } \\
\text { Suites }\end{array}$ \\
\hline Influenza & Respiratory & $\begin{array}{l}\text { Additional Precautions (Droplet } \\
\text { Transmission) } \\
\text { Single Room Or Cohort Placement In } \\
\text { Cases Of Outbreaks, Particularly For } \\
\text { Children And Elderly Patients. } \\
\text { Infected Hcws Should Not Be In } \\
\text { Contact With Patients }\end{array}$ \\
\hline Measles & $\begin{array}{l}\text { Respiratory (Airborne And Droplet } \\
\text { Spread And Direct Contact With } \\
\text { Infected Throat Or Nasal } \\
\text { Secretions. } \\
\text { Highly Communicable }\end{array}$ & $\begin{array}{l}\text { Additional Precautions (Airborne And } \\
\text { Droplet Transmission), With A Wellfitting } \\
\text { Particulate Respirator To Be } \\
\text { Worn. } \\
\text { A Negative Pressure Single Room, With } \\
\text { The Door Closed, For Infected Patients } \\
\text { During Infectious Period. } \\
\text { Preclude Non-Immune Exposed } \\
\text { Health Care Wprkers From Direct Patient Contact } \\
\text { From } 5 \text { Days After First Exposure Until } \\
21 \text { Days After Last Exposure. } \\
\text { Infected Hcws Should Be Precluded } \\
\text { From Contact With Susceptible Persons } \\
\text { Until } 7 \text { Days After Rash Appears. }\end{array}$ \\
\hline Rubella & $\begin{array}{l}\text { Respiratory (Droplet Spread) } \\
\text { Contact Spread }\end{array}$ & $\begin{array}{l}\text { Additional Precautions (Droplet } \\
\text { Transmission) And Single Room. } \\
\text { Preclude Non-Immune Exposed } \\
\text { Hcws From Direct Patient Contact }\end{array}$ \\
\hline
\end{tabular}




\begin{tabular}{|c|c|c|}
\hline & & $\begin{array}{l}\text { From } 7 \text { Days After First Exposure Until } \\
21 \text { Days After Last Exposure. } \\
\text { Infected Hcws Should Avoid Contact } \\
\text { With Susceptible Persons Until } 5 \text { Days } \\
\text { After Rash Appears. }\end{array}$ \\
\hline Tuberculosis & Respiratory (Airborne Spread) & $\begin{array}{l}\text { Additional Precautions (Airborne } \\
\text { Transmission) Use A P2 Particulate } \\
\text { Respirator } \\
\text { Negative Pressure Single Room } \\
\text { Tuberculin Skin Test-Positive Hcws } \\
\text { (With No Previous History Of A Bcg) } \\
\text { Should Be Followed Up With A Chest } \\
\text { Xray And Clinical Review. Defer Dental } \\
\text { Treatment If Possible Until Patient Is } \\
\text { No Longer Infectious }\end{array}$ \\
\hline $\begin{array}{l}\text { Cjd(Creutzfel } \\
\text { dt-Jakob } \\
\text { Disease) }\end{array}$ & $\begin{array}{l}\text { Contact With Infected Cns Or } \\
\text { Neural Tissue }\end{array}$ & $\begin{array}{l}\text { 1. Use Single Use Instruments } \\
\text { 2. Reusable Instruments Should Be A } \\
\text { Dedicated Kit For The Individual } \\
\text { Patient } \\
\text { 3. All Instruments And Materials } \\
\text { Must Be Destroyed By Incineration } \\
\text { 4. High Risk Surgical Procedures } \\
\text { Should Be Referred To A Dedicated } \\
\text { Facility } \\
\text { 5. Separate Isolated Water Supply } \\
\text { And Suction Should Be Used. }\end{array}$ \\
\hline $\begin{array}{l}\text { Varicella } \\
\text { Zoster }\end{array}$ & $\begin{array}{l}\text { Chickenpox: } \\
\text { Respiratory (Airborne) } \\
\text { Contact } \\
\text { Shingles (Localised): } \\
\text { Contact } \\
\text { Shingles (Disseminated): } \\
\text { Respiratory (Airborne) } \\
\text { Contact } \\
\text { Chickenpox And Shingles In } \\
\text { Immunocompromised Patients: } \\
\text { Respiratory (Airborne) } \\
\text { Contact }\end{array}$ & $\begin{array}{l}\text { Additional Precautions (Airborne And } \\
\text { Contact Transmission For Chickenpox } \\
\text { Or Disseminated Shingles; Contact } \\
\text { Transmission For Localised Shingles). } \\
\text { Preclude Non-Immune Exposed } \\
\text { Hcws From Direct Patient Contact } \\
\text { From } 10 \text { Days After First Exposure To } 21 \\
\text { Days After Last Exposure } \\
\text { Preclude Non-Immune Exposed } \\
\text { Hcws From Direct Patient Contact } \\
\text { From } 10 \text { Days After First Exposure To } 21 \\
\text { Days After Last Exposure } \\
\text { Infected Hcws Should Avoid Contact } \\
\text { With Susceptible Persons Until All } \\
\text { Lesions Are Dry } \\
\text { Immunodeficient Hcws Should Not } \\
\text { Be Involved In The Care Of Varicellazoster- } \\
\text { Infected Patients }\end{array}$ \\
\hline
\end{tabular}

Table 6-Additional Precautions Against Specific Disesases ${ }^{16}$

\begin{tabular}{|c|c|c|}
\hline DISEASE & WORK RESTRICTION & DURATION \\
\hline Conjuctivitis & $\begin{array}{l}\text { Restrict from patient contact and contact with } \\
\text { patient's } \\
\text { Environment }\end{array}$ & Until discharge ceases \\
\hline $\begin{array}{l}\text { Cytomegalovirus } \\
\text { infection }\end{array}$ & No restriction & \\
\hline $\begin{array}{l}\text { Diarrheal disease } \\
\text { Acuter stage } \\
\text { (diarrhea with } \\
\text { other symptoms) }\end{array}$ & $\begin{array}{l}\text { Restrict from patient contact, contact with } \\
\text { patient'snvironment, and food-handling. }\end{array}$ & Until symptoms resolve \\
\hline $\begin{array}{l}\text { Convalescent } \\
\text { stage, Salmonella } \\
\text { species }\end{array}$ & Restrict from care of patients at high risk. & $\begin{array}{l}\text { Until symptoms resolve; consult with } \\
\text { local and state health } \\
\text { authorities regarding need for negative } \\
\text { stool cultures }\end{array}$ \\
\hline $\begin{array}{l}\text { Enteroviral } \\
\text { infection }\end{array}$ & $\begin{array}{l}\text { Restrict from care of infants, neonates, and } \\
\text { immunocompromised patients and their } \\
\text { environments. }\end{array}$ & Until symptoms resolve \\
\hline Hepatitis A & $\begin{array}{l}\text { Restrict from patient contact, contact with } \\
\text { patient's }\end{array}$ & Until 7 days after onset of jaundice \\
\hline
\end{tabular}




\begin{tabular}{|c|c|c|}
\hline & environment, and food-handing. & \\
\hline $\begin{array}{l}\text { Hepatitis B } \\
\text { Personnel with } \\
\text { acute or chronic } \\
\text { hepatitis B } \\
\text { surface } \\
\text { antigenemia who } \\
\text { do not perform } \\
\text { exposure-prone } \\
\text { procedures } \\
\text { Personnel with } \\
\text { acute or chronic } \\
\text { hepatitis B } \\
\text { e antigenemia who } \\
\text { perform exposure- } \\
\text { prone } \\
\text { procedures }\end{array}$ & $\begin{array}{l}\text { No restriction; refer to state regulations. } \\
\text { Standard } \\
\text { precautions should always be followed. } \\
\text { Do not perform exposure-prone invasive } \\
\text { procedures until } \\
\text { counsel from a review panel has been sought; } \\
\text { panel } \\
\text { should review and recommend procedures that } \\
\text { personnel } \\
\text { can perform, taking into account specific } \\
\text { procedures as } \\
\text { well as skill and technique. Standard } \\
\text { precautions should } \\
\text { always be observed. Refer to state and local } \\
\text { regulations } \\
\text { or recommendations. }\end{array}$ & Until hepatitis B e antigen is negative \\
\hline Hepatitis C & $\begin{array}{l}\text { No restrictions on professional activity. HCV- } \\
\text { positive } \\
\text { health-care personnel should follow aseptic } \\
\text { technique } \\
\text { and standard precautions. }\end{array}$ & \\
\hline $\begin{array}{l}\text { Herpes simplex } \\
\text { Genital } \\
\text { Hands (herpetic } \\
\text { whitlow) } \\
\text { Orofacial }\end{array}$ & $\begin{array}{l}\text { No restriction } \\
\text { Restrict from patient contact and contact with } \\
\text { patient's } \\
\text { environment. } \\
\text { Evaluate need to restrict from care of patients at } \\
\text { high risk. }\end{array}$ & Until lesions heal \\
\hline $\begin{array}{l}\text { Human } \\
\text { immunodeficiency } \\
\text { virus; personnel } \\
\text { who } \\
\text { perform exposure- } \\
\text { prone procedures }\end{array}$ & $\begin{array}{l}\text { Do not perform exposure-prone invasive } \\
\text { procedures until } \\
\text { counsel from an expert review panel has been } \\
\text { sought; } \\
\text { panel should review and recommend procedures } \\
\text { that } \\
\text { personnel can perform, taking into account } \\
\text { specific } \\
\text { procedures as well as skill and technique. } \\
\text { Standard } \\
\text { precautions should always be observed. Refer to } \\
\text { state } \\
\text { and local regulations or recommendations. }\end{array}$ & \\
\hline $\begin{array}{l}\text { Measles } \\
\text { Active } \\
\text { Postexposure } \\
\text { (susceptible } \\
\text { personnel) } \\
\end{array}$ & $\begin{array}{l}\text { Exclude from duty } \\
\text { Exclude from duty }\end{array}$ & $\begin{array}{l}\text { Until } 7 \text { days after the rash appears } \\
\text { From fifth day after first exposure } \\
\text { through twenty-first day } \\
\text { after last exposure, or } 4 \text { days after rash } \\
\text { appears }\end{array}$ \\
\hline $\begin{array}{l}\text { Meningococcal } \\
\text { infection }\end{array}$ & Exclude from duty & $\begin{array}{l}\text { Until } 24 \text { hours after start of effective } \\
\text { therapy }\end{array}$ \\
\hline $\begin{array}{l}\text { Mumps } \\
\text { Active } \\
\text { Postexposure } \\
\text { (susceptible } \\
\text { personnel) }\end{array}$ & $\begin{array}{l}\text { Exclude from duty } \\
\text { Exclude from duty }\end{array}$ & $\begin{array}{l}\text { Until } 9 \text { days after onset of parotitis } \\
\text { From twelfth day after first exposure } \\
\text { through twenty-sixth } \\
\text { day after last exposure, or until } 9 \text { days } \\
\text { after onset of parotitis }\end{array}$ \\
\hline
\end{tabular}

Table 7-Work Restrictions For Dental Health Care Personnel ${ }^{19}$

\begin{tabular}{|l|l|}
\hline What to evaluate & How to evaluate \\
\hline Immunizations of the office staff & $\begin{array}{l}\text { Conduct an annual review of staff records to ensure upto } \\
\text { date immunizations }\end{array}$ \\
\hline Occupational exposures to infectious materials & $\begin{array}{l}\text { Report the exposures.document and review the steps that } \\
\text { occurred around the exposure and plan how it could be } \\
\text { prevented in future }\end{array}$ \\
\hline Postexposure management and follow up & $\begin{array}{l}\text { Ensure the postexposure management plan is understood } \\
\text { by all office staff and that the exposure evaluation } \\
\text { procedures are available at all times }\end{array}$ \\
\hline Hand hygiene procedures & $\begin{array}{l}\text { Observe and document circumstancesof appropriate and } \\
\text { non appropriate hand hygiene. Review findings in staff }\end{array}$ \\
\hline
\end{tabular}




\begin{tabular}{|l|l|}
\hline Use of personnel protective barriers & meeting \\
\hline Monitoring the sterilization process & $\begin{array}{l}\text { Observe and document the use of barrier precautions and } \\
\text { careful handling of sharps. Review findings in a staff } \\
\text { meeting }\end{array}$ \\
\hline Microbial quality of dental water unit & $\begin{array}{l}\text { Compare the paper log of mechanical } \\
\text { monitoring(time/temperature) chemical } \\
\text { monitoring(temperature strips) of each sterilizer load with } \\
\text { the weekly biological monitoring(spore testing) results. } \\
\text { Document that appropriate procedures are in place are } \\
\text { performed when sterilization failure occurs. }\end{array}$ \\
\hline Evaluating safety devices & $\begin{array}{l}\text { Monitor the microbial content of water exiting the dental } \\
\text { units to determine the compliance with the Environmental } \\
\text { Protection Agency drinking water standard of no more } \\
\text { than 500 CFU/ml heterotrophic bacteria }\end{array}$ \\
\hline $\begin{array}{l}\text { Conduct an annual review of the exposure control plan for } \\
\text { the documentation of new developments in s safety devices }\end{array}$ \\
\hline
\end{tabular}

Table 8-Methods To Evaluate Infection Control Program ${ }^{9}$

\section{Conclusion}

The science of dentistry has changed for the better in the past century and more so in recent years. Microorganisms are ubiquitous since they cause contamination, infection and decay, it becomes necessary to remove or destroy them from materials or from areas. This is the objective of infection control. All health care workers are frequently exposed to life threatening micro organisms.Concerns about the possible spread of blood-borne diseases, and the impact of emerging, highly contagious respiratory and other illnesses, require practitioners to establish, evaluate, continually update and monitor their infection prevention and control strategies and protocols. The purpose of infection control in a dental surgery is to prevent the transmission of disease-producing micro-organisms such as bacteria, viruses and fungi from one patient to another patient, from dental care provider to patient, and from patient to dental care provider or other dental staff. In addition to professional obligations, dentists also have an ethical duty to maintain a safe and healthy office environment for both patients and staff, and to adhere to all rules and regulations related to the operation of a dental practice, including workplace health and safety and environmental protection. The risk of infection as a result of a dental procedure is extremely low, but it represents an important patient safety consideration. By understanding how diseases are transmitted, and applying infection prevention and control principles (IPAC), OHCWs can develop strategies to interrupt the transmission of micro-organisms among patients and OHCWs, and from dental instruments, handpieces, devices and equipment

\section{References}

[1]. Best M, Neuhauser D. Ignaz Semmelweis and the birth of infection control. Qual Safe Health Care 2004 Jun;13(3):233234.

[2]. Jha AK, Prasopa-Plaizier N, Larizgoitia I, Bates DW. Patient safety research: an overview of the global evidence. Qual Safe Health Care 2010 Feb;19(1):42-47.

[3]. Mosley JW, White E. Viral hepatitis as an occupational hazard of dentists. J Am Dent Assoc 1975 May;90(5):992-997.

[4]. Kanjirath PP, Coplen AE, Chapman, JC, Peters MC. Effectiveness of gloves and infection control in dentistry: student and provider perspectives. J Dent Educ 2009 May;73(5):571-580.

[5]. Whitworh CL, Palmer N. Decontamination in primary care dentistry. J Infect Prevention 2010 Nov;11(6):200-204.

[6]. American Dental Association. Statement on infection control in dentistry; 2004. Available from: http://www.ada.org/1857.aspx.

[7]. Gupta R,Chandra S,Tandon BK: Infection control :A serious concern.J of IND Prostho Soc.2003;3(2):53-58

[8]. Roher MD,Bullard RA.Microwave steriization .JADA 1985;110:194-198

[9]. 9.Miller C H, Palenik C J, Infection Control And Management Of Hazardous Materials For The Dental Team, $3^{\text {rd }}$ ed 10.Kan B, Altay M A, Infectious Disease And Personal Protection Techniques For Infection Control In Dentistry.Infection control updates, Dr Christopher Sudhakar (Ed) ISBN:998-953-51-0055-3

[10]. Kohli A, Puttaiah R. Dental Infection Control And Occupational Safety For Oral Health Care Professionals Australian Dental Association, Guidelines For Infection Control, Second Edition, 2012

[11]. Bagg J, Sweeney CP, Roy KM, Sharp T, Smith A. Cross infection control measures and the treatment of patients at risk of Creutzfeldt Jakob Disease in UK genral dental practice. Brit Dent J 2001;191(2):8790.

[12]. Newman M G, Takei H H, Caranza F A et al.10th edition, Caranza's Clinical Periodontology 2011 Ohio State Dental Board, Infection Control Manual, 2011 April St Louis Robinson D, Bird D. Modern dental assisting, ed 10, Ch 19 Disease Transmission And Infection Prevention, , 2011 p. 281-316.

[13]. Griffith University, School Of Dentistry And Oral Health, Infection Control Procedure Manual 2009

[14]. The Dental Council, 57 Merrion Square, Dublin 2, Code Of Practice Relating To Infection Control In Dentistry Department Of Health And Human Services, Centres For Disease Control And Prevention, Guidelines For Infection Control In Dental Health Care Settings-2003.

[15]. College Of Dental Hygienists Of British Columbia, Infection Prevention And Control Guidelines, July 2012

[16]. The New Zealand Dental Association And The Dental Council Of New Zealand, Control Of Cross Infection In Dental Practice, August 2007

[17]. Cottone's practical infection control in dentistry.Third edition Roberson T M, Heymann H O, Swift E J, Strudevant's Art And Science Of Operative / Dentistry, $5^{\text {th }}$ Edition Dickinson S K, Bebemeyer R D, Guidelines For Infection Control In Dental Health Care Settings, July 2013. 
[18]. British Dental Association, Advice sheet, infection control in dentistry. Centers for disease control and prevention. Guidelines for Infection Control in Dental Health Care Setting ---2003. 2003/52(RR17);1-97.

[19]. Altaf H Shah, Amjad H Wyne.,Cross - infection control in dentistry: a review.,Pakistan Oral \& Dental Journal Vol 30, No. 1, (June 2010). 